\title{
DA ZONA DA MATA/MG À REGIÃO GEOGRÁFICA INTERMEDIÁRIA DE JUIZ DE FORA/MG: CONTINUIDADES E DESCONTINUIDADES NAS PROPOSTAS DE REGIONALIZAÇÃO DO IBGE
}

\author{
Samarane Fonseca de Souza Barros \\ Doutoranda em Geografia, Mestra em Geografia (UFJF) \\ Universidade Estadual Paulista, Faculdade de Ciências e Tecnologia \\ Presidente Prudente, SP, Brasil \\ s.barros@unesp.br
}

\begin{abstract}
RESUMO
O trabalho que segue tem como objetivo principal identificar as continuidades $\mathrm{e}$ descontinuidades entre a Zona da Mata/MG e a Região Geográfica Intermediária de Juiz de Fora/MG, dois recortes regionais propostos pelo Instituto Brasileiro de Geografia e Estatística (IBGE) em 1990 e 2017 respectivamente. Para tanto, resgatou-se outras regionalizações propostas pelo Instituto para o estado de Minas Gerais e a geo-história do recorte empírico a ser analisado. Metodologicamente, recorreu-se a levantamento bibliográfico e documental, além da elaboração de mapas e quadros que auxiliaram na compreensão final do texto. Observou-se que entre as regionalizações de 1990 e 2017 há mais permanências do que rupturas para a área, sendo que a última regionalização ratificou a centralidade de Juiz de Fora como principal polo, além de identificar outras cidades que também desempenham papéis importantes e articulam recortes regionais menores.
\end{abstract}

Palavras-chave: IBGE. Região. Minas Gerais. Juiz de Fora. Recortes políticoadministrativos.

\section{FROM THE "ZONA DA MATA/MG" TO THE "REGIÃO GEOGRÁFICA INTERMEDIÁRIA DE JUIZ DE FORA/MG": CONTINUITIES AND DISCONTINUITIES IN IBGE'S REGIONALIZATION PROPOSALS}

\begin{abstract}
The work that follows has the main objective of identifying the continuities and discontinuities between the "Zona da Mata/MG" and the "Região Geográfica Intermediária de Juiz de Fora/MG", two regional cutouts proposed by the Brazilian Institute of Geography and Statistics (IBGE) in 1990 and 2017 respectively. For this purpose, other regionalizations proposed by the institute for the state of Minas Gerais and the geo-history of the empirical cutout to be analyzed were rescued. Methodologically, there was a bibliographic and documentary survey, in addition to the elaboration of maps and tables that help in the final understanding of the text. It was observed that between the 1990 and 2017 regionalizations there are more permanences than ruptures for the area, with the last regionalization ratifying the centrality of Juiz de Fora as the main pole, in addition to identifying smaller cities that also play important roles and articulate smaller regions.
\end{abstract}

Keywords: IBGE. Region. Minas Gerais. Juiz de Fora. Political-administrative cuts.

\section{INTRODUÇÃO}

O debate sobre região e regionalização sempre esteve presente no âmbito geográfico por transitar entre elementos teórico-metodológicos e também expressar uma dimensão empírica e concreta. Ao longo dos paradigmas geográficos e com as alterações espaço-temporais, o conceito de região foi sendo ressignificado (SOUZA, 2013), assim como as regionalizações perpassaram por uma "grande variabilidade histórico-geográfico-cultural" (SOUZA, 2013, p. 146). Todavia, observa-se que há similitudes concernentes ao conceito de região, sobremaneira, se for resgatada a etimologia da palavra atrelada a domínio e poder (DINIZ; BATELLA, 2005), o que faz com que a noção de região, em muito, seja empregada para ações políticas desde os impérios romano e persa (RUA et al, 1993), sendo um importante recorte para órgãos de planejamento.

Isto posto, resgatou-se aqui os estudos e propostas de regionalização feitos pelo Instituto Brasileiro de Geografia e Estatística (IBGE), considerando este o órgão responsável pelos levantamentos e divulgações de dados territoriais brasileiros, para o estado de Minas Gerais, a fim de traçar uma análise comparativa, sobremaneira, entre as duas últimas regionalizações (IBGE, 1990; 2017). Para 
analisar as continuidades e descontinuidades entre a "Divisão Regional do Brasil em Mesorregiões e Microrregiões Geográficas" (IBGE, 1990) e a "Divisão Regional do Brasil em Regiões Geográficas Imediatas e Regiões Geográficas Intermediárias" (IBGE, 2017), elegeu-se como recorte empírico o leste do estado de Minas Gerais onde está localizada a maior região geográfica intermediária do país: a região geográfica intermediária de Juiz de Fora (IBGE, 2017) que coincide à, parcialmente, a mesorregião geográfica da Zona da Mata (IBGE, 1990).

As regionalizações anteriores (IBGE, 1942 apud Contel, 2014; IBGE, 1970) foram resgatadas considerando que elas são os planos de fundo para as regionalizações mais recentes, assim como o estudo sobre regiões funcionais urbanas que forneceu subsídio teórico-metodológico para as presentes propostas de regionalização do território brasileiro.

Vale colocar que as regionalizações são atualizadas face as novas demandas que surgem a partir de alterações territoriais, assim como a partir de novos conceitos históricos, geográficos e políticos, sendo cada regionalização proposta em um contexto específico. Nesta direção, uma regionalização não é mais valorosa e tampouco anula a precedente; é apenas uma nova forma de configuração do território que servirá como base para a divulgação de dados estatísticos oficiais e para a ação do Governo para implementação de projetos (IBGE, 2017).

Para atingir o objetivo maior do texto que é analisar as continuidades e descontinuidades entre as regionalizações de 1990 e 2017 do IBGE para o leste do estado de Minas Gerais, metodologicamente, recorreu-se a textos científicos sobre região, regionalização e sobre o recorte empírico do presente texto, além de documentos oficiais do IBGE e os textos originais de cada publicação de divisão regional. Após o levantamento bibliográfico e documental, foram cartografados mapas no software ArcGIS 10.1 e foram feitos quadros e tabelas que somaram ao entendimento final do texto. Os textos e documentos estão referenciados ao fim do artigo.

O presente texto, então, segue dividido em outras três partes, além dessa introdução e das considerações finais. Na primeira seção foi realizado um resgate geo-histórico sobre as primeiras regionalizações propostas pelo IBGE no início do século XX, dando ênfase para a configuração do estado de Minas Gerais. Já na segunda parte, focou-se em traçar uma análise comparativa entre as regionalizações de 1990 e 2017, a fim de levantar semelhanças e diferenças teórico-metodológicas. Por fim, a última parte é destinada a analisar as continuidades e descontinuidades das duas últimas regionalizações e/ou entre a mesorregião geográfica da Zona da Mata mineira e a região geográfica intermediária de Juiz de Fora.

\section{UM RESGATE GEO-HISTÓRICO SOBRE AS PROPOSTAS DE REGIONALIZAÇÃO DO IBGE PARA MINAS GERAIS}

A região enquanto conceito e categoria de análise em Geografia apresentou êxito, sobremaneira, na primeira metade do século $\mathrm{XX}$ quando era apontada por um grande número de geógrafos como o elemento central dessa ciência (SOUZA, 2013). No entanto, na segunda metade desse mesmo século o conceito foi submetido a inúmeras críticas que colocaram em cheque a sua validade teóricometodológica, levando Lacoste (1988) a designar a região como um "conceito-obstáculo".

O conceito de região é parte da tradição geográfica e, por sua vez, evoluiu e se transformou juntamente ao desenrolar do tempo e das alterações socioespaciais. A região é definida pelos geógrafos, tradicionalmente, a partir de dois princípios básicos: a homogeneidade e a funcionalidade, sendo o primeiro atrelado a ocorrência de certas características no espaço e o segundo à relação entre as áreas (DINIZ; BATELLA, 2005). O ato de reconhecer a diferenciação de áreas e pautar um recorte para este processo é o par indissociável regionalização e região, o qual Haesbaert (2001, p. 278) difere e conceitua como sendo: a regionalização enquanto "produto de um reconhecimento de diferenciação no/do espaço geográfico" e a região o recorte geográfico deste processo.

Diniz e Batella (2005) colocam que a palavra região deriva do latim regere que, por sua vez, significa domínio e poder, sendo, portanto, o conceito atrelado historicamente a comandos políticos de ação e controle na administração de territórios. Nesta direção, inúmeros Governos, instituições e órgãos se valem do processo de regionalização para formulação de seus projetos e planos de ação, a depender do objetivo de cada um deles, uma vez que "haverá tantas regiões quantos forem os conceitos, critérios e objetivos empregados no processo de regionalização" (FJP, 1992 apud Diniz; Batella, 2005, p. 62). 
A criação do IBGE demonstra a preocupação do Governo central para com os estudos territoriais brasileiros e controle político-administrativo do território, sendo o órgão "a maior agência de planejamento territorial do governo brasileiro" (ALMEIDA, 2003, p. 79). Como tal, coube ao IBGE desde a sua criação em 1938 as principais propostas de regionalização do território brasileiro. Vale colocar que antes disso estudos sobre a configuração territorial do Brasil já vinham sendo realizados de maneira pulverizada por outros órgãos do Governo Federal, autarquias estaduais e inúmeros intelectuais, porém, a partir da criação do IBGE houve de maneira centralizada a maior sistematização, coligação e coordenação de dados bibliográficos e cartográficos do território nacional (CONTEL, 2014). Dito isto, este trabalho se apoiará nas divisões regionais propostas pelo IBGE para o estado de Minas Gerais, considerando este o principal órgão responsável por tais classificações para o Brasil.

A primeira divisão regional proposta pelo IBGE foi pensada logo em sua criação ao fim da década de 1930, todavia, foi divulgada apenas em 1941 com a publicação de Fábio Macedo Soares Guimarães na Revista Brasileira de Geografia; logo após, a divisão regional foi institucionalizada na circular número 1 de 31 de janeiro de 1942 da Secretaria da Presidência da República (CONTEL, 2014). Guimarães, então responsável pela divisão regional de 1942, coloca que as regiões naturais deveriam estar na base da regionalização do território brasileiro por possuírem, principalmente, mais estabilidade ao longo do tempo e possibilitarem melhores condições para coleta e comparação de dados ao longo do tempo (CONTEL, 2014, p. 4).

$\mathrm{Na}$ divisão a partir de regiões naturais, então, o território nacional foi repartido em cinco grandes regiões: Norte, Nordeste, Leste, Sul e Centro Oeste; que se subdividiam até as zonas fisiográficas, que eram unidades regionais menores definidas por "características sócio-econômicas, porém circunscritas à área da unidade imediatamente superior, definida pelas condições naturais" (GALVÃO; FAISSOL, 1969, p. 181). Diniz e Batella (2005, p. 65) colocam que nas zonas fisiográficas houve a adoção de alguns pressupostos da região geográfica lablacheana e, portanto, diminuição no peso de fatores físicos para a compartimentação do espaço, sendo essa divisão a base para produção e divulgação dos indicadores sociais e econômicos dos censos de 1950 e 1960.

O estado de Minas Gerais era dividido em 17 zonas fisiográficas que respeitavam os limites estaduais e eram dadas a partir de bases humanas e econômicas (DINIZ; BATELLA, 2005) (Figura 1). Contudo, Galvão e Faissol (1969) colocam que essa regionalização passou a enfrentar problemas, mormente, a partir de sucessivas emancipações municipais, além de não convergir com as macrorregiões que eram definidas a partir de outros fatores ecléticos, dificultando a compilação e tratamento de dados estatísticos.

Figura 1 - Minas Gerais: zonas fisiográficas em 1942.

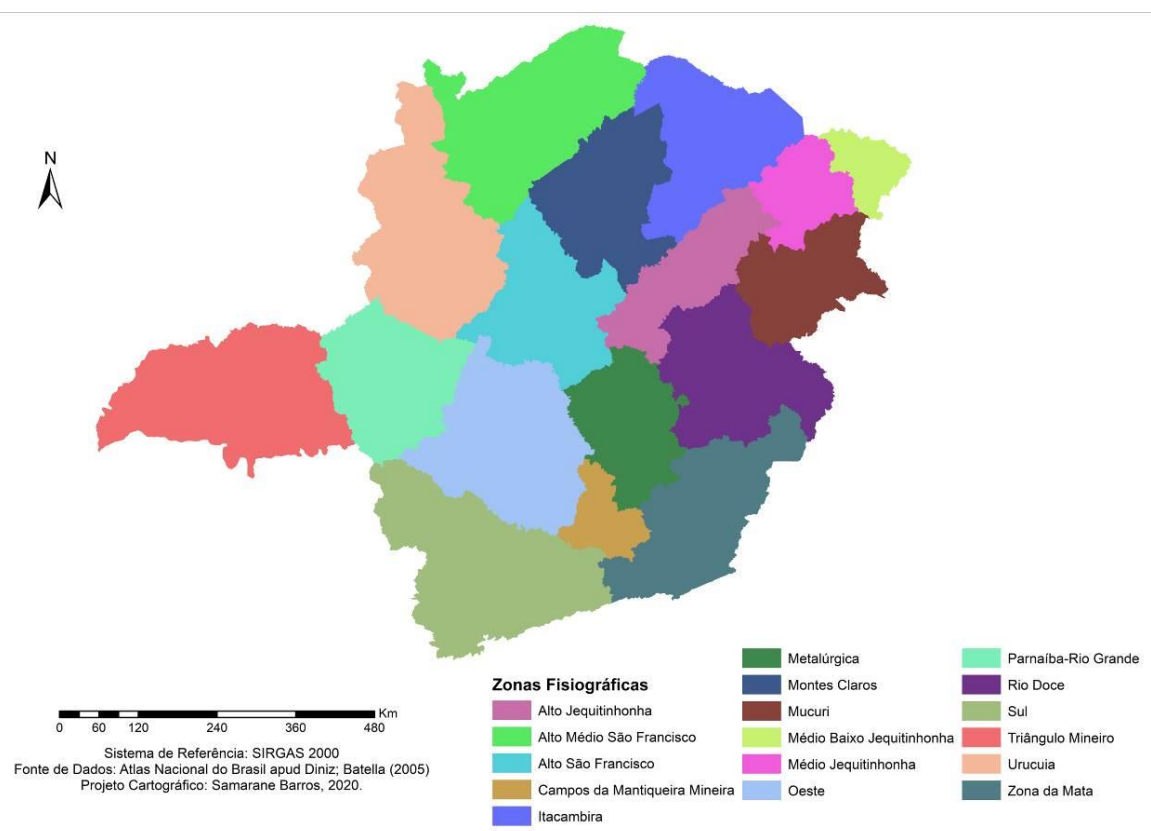

Fonte - Atlas Nacional do Brasil IBGE 2000 apud Diniz; Batella, 2005. Organização própria. 
Além dos problemas acima relacionados, a regionalização de 1942 passou a ficar datada considerando a rápida urbanização na qual o Brasil passou pós-segunda Guerra Mundial, quando o processo de industrialização se acelerou e o meio-técnico-científico passou a se difundir no território, através da expansão da rede de infraestruturas relacionadas ao transporte, energia e outros suportes (CONTEL, 2014, p. 5). Neste sentido, as regiões naturais não mais sustentariam o território brasileiro cada vez mais tecnificado e, as lacunas metodológicas da regionalização de 1942 seriam entraves para os planos estratégicos do regime autoritário instalado pós Golpe Militar de 1964.

Os princípios de regionalização propostos na década de 1940 para atender uma série de fins diversos foram mudados para uma nova regionalização do território nacional baseada, principalmente, em dados econômicos e cujo objetivo era "fornecer critérios básicos para o emprego dos vários instrumentos de política econômica de caráter quantitativo (...) ou de caráter qualitativo (...)" (CONTEL, 2014, p. 7). Ao fim da década de 1960, então, foi proposta uma nova regionalização, em muito, influenciada por pressupostos da New Geography, além de propostas baseadas em economistas, como a Teoria dos Polos de Crescimento de François Perroux e a metodologia desenvolvida pelo geógrafo Michel Rochefort para o estudo de cidades e regiões baseado na vida de relação dos espaços (CONTEL, 2014).

Nesta direção, em 1969 foi divulgada pelo IBGE uma nova proposta baseada em três divisões regionais específicas que visavam atender ora objetivos estatísticos, de descentralização da ação administrativa ou de planejamento econômico. O país então se dividiu em grande cinco regiões: Norte, Sul, Sudeste, Nordeste e Centro-Oeste, além do reconhecimento de microrregiões homogêneas pautadas em uma forma de organização em torno da produção, além da combinação de fatores físicos, sociais e econômicos (IBGE, 1970). As microrregiões homogêneas, portanto, substituíram as zonas fisiográficas propostas na década de 1940. O estado de Minas Gerais passava a apresentar de acordo com a regionalização de 1969, destarte, 46 microrregiões homogêneas (Figura 2).

Figura 2 - Minas Gerias: microrregiões homogêneas em 1969.
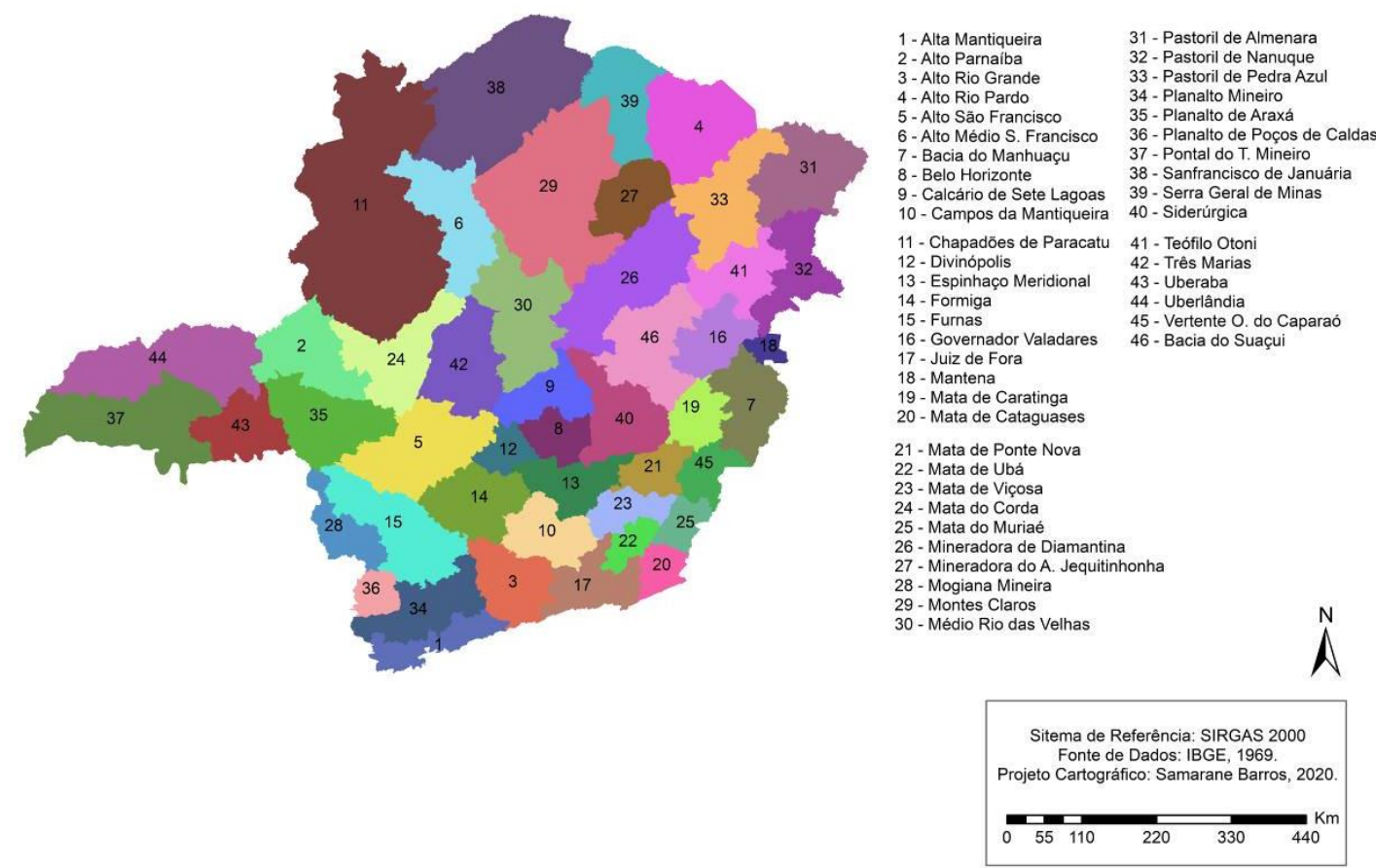

Fonte - IBGE, 1969. Organização própria.

É válido sublinhar que a partir da regionalização da década de 1960 e/ou para se chegar nela o estudo das redes urbanas passou a ser condição imprescindível tanto em aspectos práticos quanto

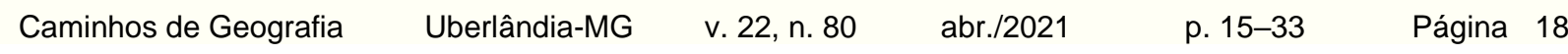


nos teóricos, sendo mencionados os conceitos de homogeneidade e funcionalidade para embasamento das análises e propostas de regionalização subsequentes (CONTEL, 2014, p. 9). Neste escopo, em 1972 o IBGE lançou um estudo regional baseados em Regiões Funcionais Urbanas, evidenciando ainda mais as influências da New Geography e os métodos de análise regional (DINIZ; BATELLA, 2005, p. 67). Vale colocar que o estudo de 1972 não se configurou como uma divisão regional oficial tais quais as dos anos precedentes, porém, foi aqui acionado por subsidiar uma série de análises e regionalizações funcionais subsequentes.

A delimitação de Regiões Funcionais Urbanas foi o esboço de publicações posteriores do IBGE relacionadas à Região de Influência das Cidades (REGIC) (IBGE, 2008) e dividia os centros urbanos a partir de relações de dominância e subordinação, classificando-os em quatro níveis, a saber: Centros Metropolitanos, Centros Regionais, Centros Sub-regionais e Centros Locais (IBGE, 1972).

No estudo de 1972, as cidades foram consideradas como estruturas marcadas pela presença de economias básicas, podendo estabelecer relações com outras cidades e regiões, sendo a definição da divisão territorial dada a partir da contagem de relacionamentos entre os centros urbanos em três níveis: fluxos agrícolas, distribuição de bens e serviços à economia e à população (IBGE, 1972). É válido ressaltar que neste estudo por considerar, principalmente, os fluxos entre as cidades e não se tratar de uma divisão oficial para fins estatísticos, os limites político-administrativos não foram levados em consideração.

O estado de Minas Gerais, neste estudo, tinha uma metrópole principal - Belo Horizonte - que tinha em sua região urbana quatro centros regionais: Governador Valadares, Teófilo Otoni, Montes Claros e Divinópolis. No entanto, havia no estado outros centros regionais que se vinculavam à outras regiões urbanas em função da maior proximidade e troca de fluxos, são eles: Juiz de Fora e Muriaé vinculados a região urbana do Rio de Janeiro e, Uberlândia e Varginha vinculadas à região urbana de São Paulo (IBGE, 1972). Na figura 3 tem-se a distribuição da metrópole e dos centros regionais em Minas Gerais.

Figura 3 - Minas Gerais: Regiões Funcionais Urbanas em 1972.

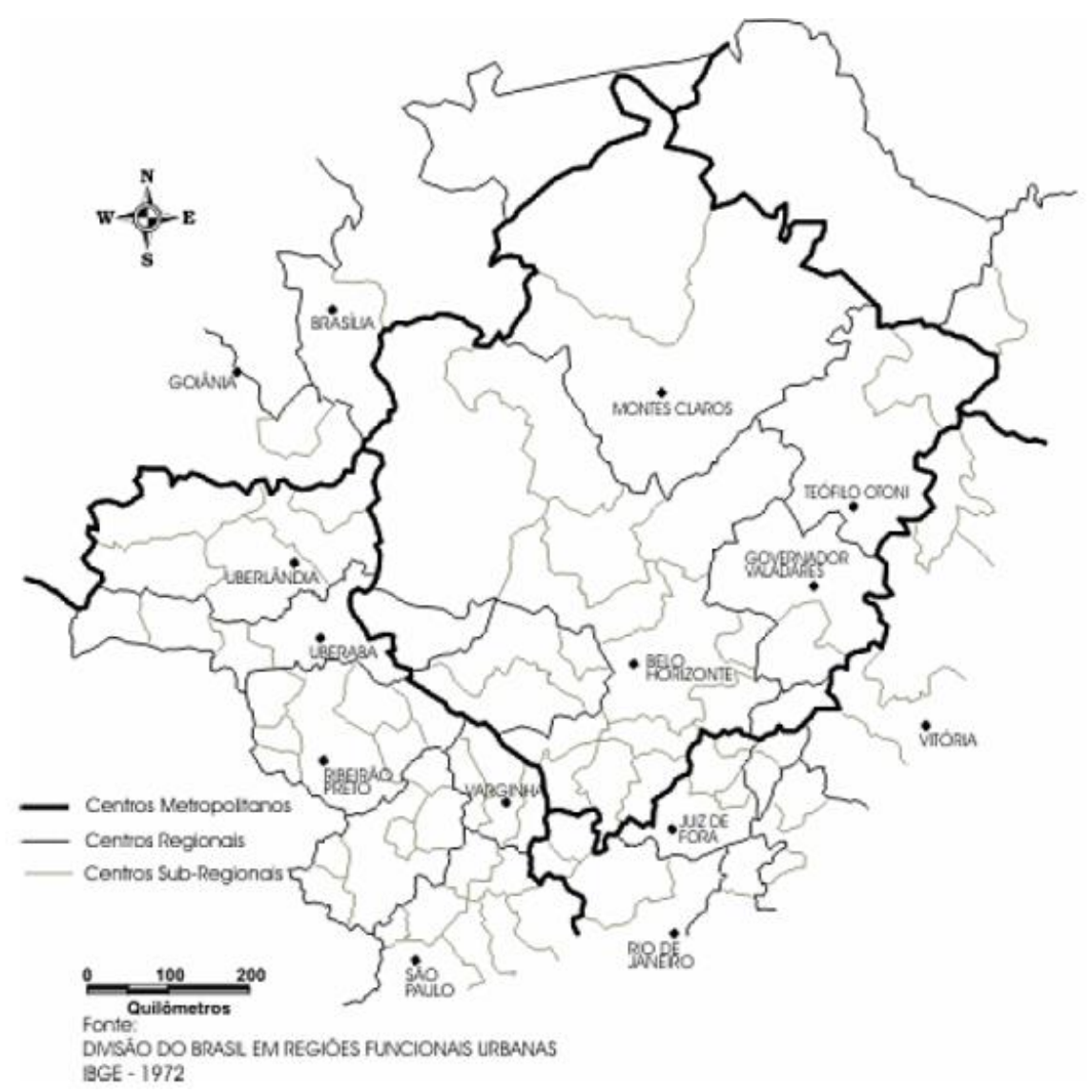

Fonte - Diniz; Batella, 2005. 
O estudo de 1972, então, abriu precedente para outros estudos sobre a taxonomia e hierarquização das áreas urbanas brasileiras, como já colocado. Ademais, o reconhecimento de cidades importantes foi utilizado para as regionalizações propostas pelo IBGE em 1990 e 2017, conforme será abordado adiante, no que tange a denominação de mesorregiões e microrregiões geográficas e, posteriormente, regiões geográficas intermediárias e regiões geográficas imediatas (IBGE, 1990; 2017).

\section{ANÁLISE COMPARATIVA ENTRE AS REGIONALIZAÇÕES DE 1990 E 2017}

O cenário brasileiro em 1990 era semelhante ao encontrado ao fim da década de 1970, sendo o modal rodoviário o predominante e o meio técnico-científico difundido pelo território nacional de maneira desigual, sendo as assimetrias regionais somadas a uma série de especializações produtivas (SANTOS; SILVEIRA, 2008). Diniz (1993) sobre a difusão da indústria e do meio técnico-científico pelo território nacional coloca que há maior desconcentração para além de áreas tradicionais da industrialização brasileira, contudo, a desconcentração se dá de maneira concentrada e seletiva em um polígono delimitado pelo autor que permeia Belo Horizonte-Uberlândia-Londrina/Maringá-Porto Alegre-Florianópolis-São José dos Campos-Belo Horizonte.

Dentre alguns fatores que permitiram a desconcentração industrial pelo território brasileiro na década de 1990, estão a abertura econômica e do mercado e o reescalonamento do Estado. O primeiro fator permitiu a comercialização de produtos finais em mais pontos ao interior do território nacional enquanto o segundo atrelou-se ao avanço do receituário neoliberal que, a partir da privatização de setores estratégicos de infraestrutura, também propiciou a maior chegada de redes técnicas pelo interior do Brasil (AMORIM FILHO; SERRA, 2001).

Sobre a questão estatal e da macro-política nacional, Contel (2014, p. 10) reconhece que a ascensão de governos de cunhos neoliberais "fomentou ainda mais a competitividade territorial e a "guerra dos lugares' na formação socioespacial brasileira". O autor segue e demonstra que as mudanças da conjuntura nacional repercutiram na organização do IBGE e, por conseguinte, nas propostas de regionalização para o território brasileiro.

A proposta denominada "Divisão Regional do Brasil em Mesorregiões e Microrregiões Geográficas foi fruto do trabalho do grupo "Divisão de Estudos Territoriais" circunscrito ao IBGE, sendo institucionalizada definitivamente em 1990 (IBGE, 1990). Dentre os objetivos de tal regionalização estava a preocupação de apreender as transformações territoriais brasileiras, sobretudo, no tocante a maior participação do interior do país em cadeias de escala mundial (IBGE, 2017) como efeito a uma maior globalização e neoliberalização da economia. Ademais, a nova regionalização lançada logo após a Constituição de 1988 reforçava o movimento de descentralização do poder indo ao encontro do texto da Lei Maior que

(...) consagrava um pacto federativo que não só aprofunda a competência de estados e municípios sobre seus respectivos territórios, mas também é pautado, principalmente, pela ampliação da participação da sociedade e das instituições públicas e privadas na gestão do território brasileiro (BRASIL, 2012 apud IBGE, 2017, p. 18).

Nesta nova proposta de regionalização, o território nacional foi dividido ora em mesorregiões geográficas, ora em microrregiões geográficas que partiam das unidades de federação como recorte principal e a partir do método de divisão sucessiva dos espaços, à posteriori, foram reconhecidas as mesorregiões e microrregiões que adotaram a denominação geográfica em substituição a expressão homogênea da proposta anterior (IBGE, 1990).

Faissol (1996 apud Diniz; Batella, 2005, p. 70) coloca que para além da divulgação dos dados em escalas maiores ou menores, deve-se atentar também para a unidade municipal, pois se as meso ou microrregiões não representarem efetivamente as realidades socioeconômicas, "os dados divulgados 
podem dar uma falsa ideia desta realidade, comprometendo, por sua vez, o planejamento e a execução de políticas de intervenção espacial".

As mesorregiões geográficas aparecem definidas como:

Áreas individualizadas em uma unidade da Federação que apresentam formas de organização do espaço geográfico definidas pelas seguintes dimensões: o processo social como determinante; o quadro natural como condicionante; e a rede de comunicação e de lugares como elemento da articulação espacial (IBGE, 1990, p. 8).

Por sua vez, as microrregiões foram definidas como:

Partes das mesorregiões que apresentam especificidades quanto à organização do espaço. Essas especificidades não significam uniformidade de atributos nem conferem às microrregiões autosuficiência e tampouco o caráter de serem únicas devido à sua articulação a espaços maiores, quer à mesorregião, à Unidade da Federação, quer à totalidade nacional. Essas especificidades referem-se à estrutura de produção agropecuária industrial, extrativismo mineral ou pesca. Essas estruturas de produção diferenciadas podem resultar da presença de elementos do quadro natural ou de relações sociais e econômicas particulares (IBGE, 1990, p.8).

Metodologicamente, a regionalização partiu de bases teórico-conceituais para sua posterior operacionalização. Como já citado, a divisão partia das unidades da federação e identificava, subsequentemente, outras escalas regionais (IBGE, 1990).

Os procedimentos metodológicos para a identificação das mesorregiões geográficas partiam de instrumentais, como análises bibliográfica e cartográfica, para estudo dos quadros sociais e de condicionantes naturais e, instrumentais para o estudo da articulação espacial, como a análise de cartogramas sobre a área de influência dos centros metropolitanos e regionais e a análise de mapas rodoviários e demais fluxogramas sobre redes de transporte (IBGE, 1990). A partir disso, observou-se que as mesorregiões eram unidades que apresentavam forte identidade regional, sendo essa uma realidade construída ao longo do tempo pelas sociedades que abrigavam cada um desses recortes.

Por sua vez, os procedimentos metodológicos para identificação das microrregiões geográficas partiam de dois indicadores: a estrutura da produção e a interação espacial que resultariam na "presença de elementos do quadro natural ou de relações sociais e econômicas particulares (...)" (IBGE, 1990, p. 8). Isto posto, foram definidas seis etapas para a definição dos recortes microrregionais, a saber: 1) a partir das mesorregiões, buscou-se a consistência interna das microrregiões ali inseridas através de testes estatísticos de coeficiente de variação com base no censo agropecuário de 1980 ; 2) os resultados da etapa precedente foram mapeados a fim de selecionar variáveis e indicadores; 3 ) foram feitas tabelas e mapas de indicadores e variáveis conforme as informações da Sinopse Preliminar do Censo Agropecuário e da Produção Pecuária Municipal a fim de avaliar o grau de similitude dos municípios componentes das microrregiões; 4) elaboração de cartograma com fluxos de comercialização de produtos agrícolas em associação ao cartograma já existente sobre a comercialização de bens e serviços objetivando a identificação da interação entre as áreas; 5) justaposição da estrutura de produção e da interação espacial dos lugares para identificação das estruturas internas de cada microrregião e; 6) elaboração de um cartograma a partir dos agregados espaciais, permitindo a listagem das microrregiões por unidades da federação (IBGE, 1990, p. 11).

Nesta direção, foram reconhecidas em Minas Gerais na regionalização de 1990, 12 mesorregiões geográficas e 66 microrregiões geográficas que recebiam os nomes conforme os critérios estabelecidos pelo IBGE: para as mesorregiões denominações a partir de variáveis regionais importantes ou denominações a partir de centros urbanos de grandes importâncias regionais ou regiões metropolitanas e, para as microrregiões denominações a partir do município mais tradicional 
que apresenta peso na articulação do espaço ou posição significativa dentro dos estudos de região de influência das cidades (Figura 4) (IBGE, 1990).

Figura 4 - Minas Gerais: mesorregiões e microrregiões geográficas em 1990.
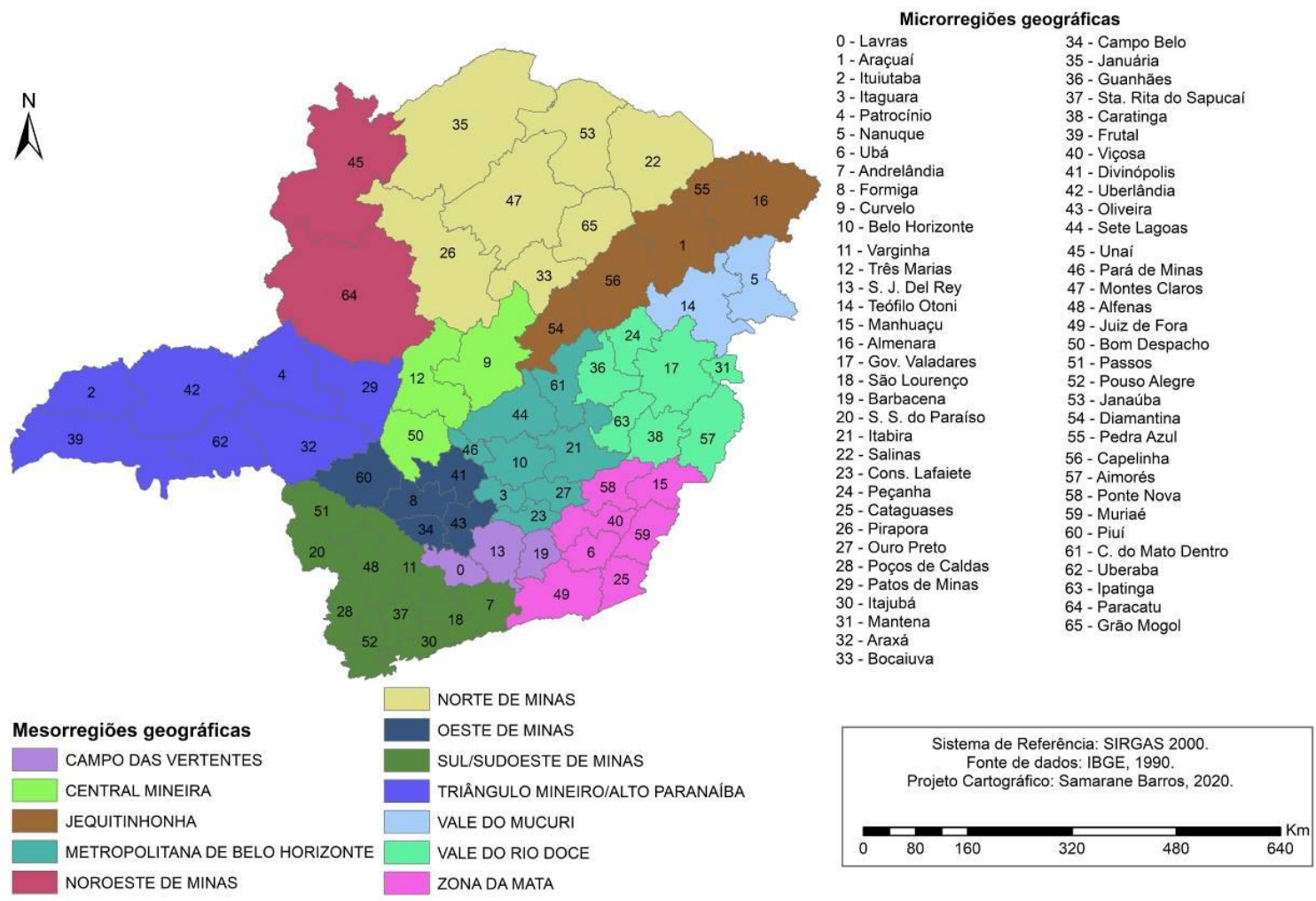

Fonte - IBGE, 1990. Organização própria.

Em 2017, o IBGE mais uma vez veio a atualizar a regionalização para o território nacional face

As mudanças ocorridas na dinâmica econômica do mundo, a inserção do Brasil nos circuitos mundiais, as novas polarizações globais, e tendo em vista, ainda, que o território brasileiro vem passando por intenso processo de transformação, que precisa ser identificado em sua diversidade (...) (IBGE, 2017, p. 19).

O IBGE (2017) coloca, então, que a atualização das mesorregiões e microrregiões geográficas para, respectivamente, as regiões geográficas intermediárias e regiões geográficas imediatas vem para incorporar as mudanças sociais, políticas e econômicas ocorridas no Brasil nas três últimas décadas. A partir dessa regionalização, portanto, o IBGE buscou apreender os recentes processos de fragmentação e articulação do território brasileiro a partir de dinâmicas multiescalares as quais complexificam a divisão espacial do trabalho e cristalizam regiões pautadas ora por uma ordem mais horizontal, ora por uma ordem mais reticular. Para tal, a regionalização resgatou os conceitos de território-rede e território-zona (HAESBAERT, 2004), sendo o primeiro atrelado aos movimentos, fluxos e diferentes formas de mobilidade e o segundo dizendo respeito as continuidades territoriais $\mathrm{e}$ relações marcadas pela fixidez e continuidade.

Considerando a expressiva urbanização do território brasileiro, o IBGE em 2017 recorreu, metodologicamente, a estudos pretéritos sobre rede urbana, classificação, fluxos de gestão do território, dentre outros, a fim de delimitar a região uma "construção do conhecimento geográfico, delineada pela dinâmica dos processos de transformação ocorridos recentemente e operacionalizada a partir de elementos concretos (...)" (IBGE, 2017, p. 19). Os estudos, mais especificamente, foram: 
Região de Influência das Cidades - REGIC, 2007; Divisão Urbano-Regional; Gestão do Território 2014; Logística dos Transportes do Brasil 2014 e Arranjos Populacionais e Concentrações Urbanas no Brasil (IBGE, 2017, p. 22). Logo após a etapa de levantamento bibliográfico que auxiliou nas premissas para definição das regiões, foi feita uma avaliação pelas Agências e Unidades Estaduais do IBGE e também por Secretarias e Institutos de Planejamento Estaduais. Por fim, foram realizados trabalhos de campo e visitas técnicas a fim de apresentar os recortes regionais aos técnicos locais responsáveis pelo planejamento do território.

A partir, portanto, de estudos pretéritos a regionalização de 2017 baseou-se na identificação de cidades-polo e de destaque na rede urbana responsáveis por articular municípios vinculados a cada uma delas. As regiões geográficas imediatas "têm na rede urbana o seu principal elemento de referência (...)" (IBGE, 2017, p. 20) e se estruturam

a partir de centros urbanos próximos para a satisfação das necessidades imediatas das populações, tais como: compras de bens de consumo duráveis e não duráveis; busca de trabalho; procura por serviços de saúde e educação; e prestação de serviços públicos, como postos de atendimento do Instituto Nacional do Seguro Social - INSS, do Ministério do Trabalho e de serviços judiciários, entre outros (IBGE, 2017, p. 20).

Já as regiões geográficas intermediárias representam uma escala intermediária entre os estados e as regiões imediatas, sendo responsáveis por organizar:

o território, articulando as Regiões Geográficas Imediatas por meio de um polo de hierarquia superior diferenciado a partir dos fluxos de gestão privado e público e da existência de funções urbanas de maior complexidade (IBGE, 2017, p. 20).

Da mesma forma que as mesorregiões e as microrregiões geográficas, as regiões intermediárias e as regiões imediatas são balizadas pelos limites político-administrativos das unidades de federação. Essa medida é tomada para facilitar as divulgações de dados estatísticos e a ação de órgãos de planejamento. Além disso, os novos recortes regionais apresentam limites em termos de número máximo e mínimo de municípios associados a cada uma das regiões a fim de manter uma proporcionalidade territorial e municipal, sendo necessárias regras e metodologias específicas para cada um dos recortes regionais (IBGE, 2017).

As regiões imediatas são formadas de 5 a 25 municípios, resguardando as particularidades de cada área, podendo, portanto, ter exceções a este quantitativo. Respeitou-se também os limites estaduais, mesmo que a área de influência do município polo extrapole a unidade de federação. Para cada região imediata, há a existência de um polo que articula o seu território, podendo este polo ser um município isolado ou um arranjo populacional (IBGE, 2017).

As regiões intermediárias, por sua vez, se baseiam nas regiões de articulação urbana e são delimitadas pelas regiões imediatas. Aqui reside mais uma diferença da regionalização de 1990 para a de 2017: se as regiões imediatas são as unidades fundamentais e indivisíveis das regiões intermediárias, na divisão regional de 1990 as mesorregiões foram elaboradas antes das microrregiões, sendo a fragmentação das primeiras que originaram as segundas. Em 2017, o processo inverso foi feito: o agrupamento das regiões imediatas dá origem as regiões intermediárias.

Nesta direção, se o número de municípios balizava a construção das regiões imediatas, para as regiões intermediárias o que balizará a sua delimitação será o número de regiões imediatas, sendo necessário no mínimo duas imediatas para cada intermediária. As regiões intermediárias são articuladas por um polo mais complexo o qual é referência "como destino para um conjunto de atividades por grande número de municípios" (IBGE, 2017, p. 33). Mais uma vez, no entanto, existem casos de exceção que podem fugir a essas regras gerais em função da diversidade do território brasileiro e particularidade de cada local.

Os nomes destinados às regiões intermediárias e imediatas seguiram a direção de ressaltar os maiores polos da hierarquia urbana de cada uma delas (IBGE, 2017) sendo, portanto, uma regionalização que dentre outros fins, buscou relevar a articulação entre as cidades. $\mathrm{Na}$ regionalização de 1990 já se observava o movimento de sublinhar o destaque de alguns centros

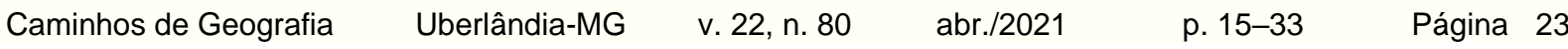


urbanos, no entanto, no caso das mesorregiões geográficas se observava ainda as toponímias associadas a traços regionais importantes.

Isto posto, o estado de Minas Gerais está dividido em 13 regiões geográficas intermediárias e 70 regiões geográficas imediatas (Figura 5) (IBGE, 2017).

Figura 5 - Minas Gerais: Regiões Geográficas Intermediárias e Imediatas em 2017.

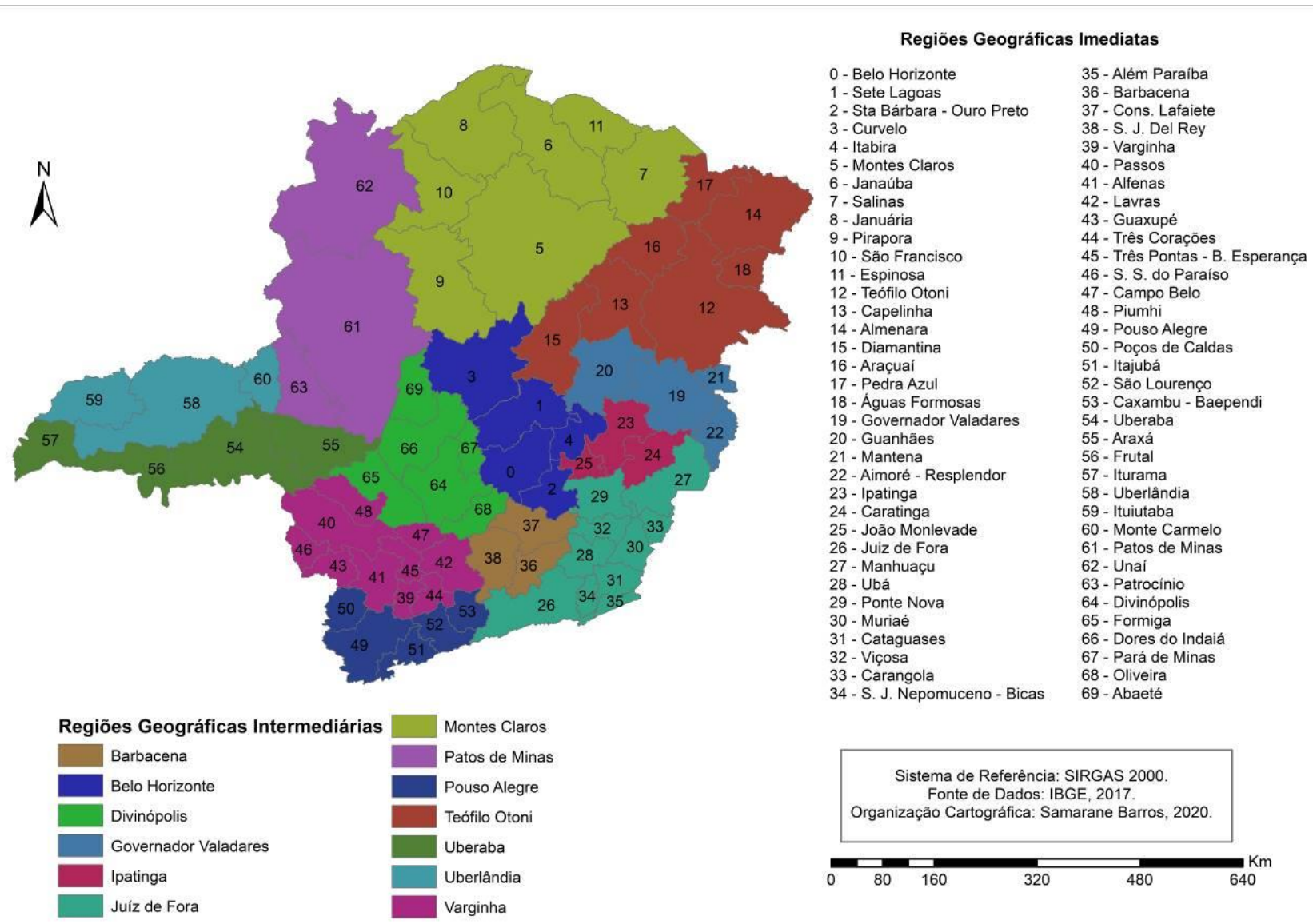

Fonte - IBGE, 2017. Organização própria.

Em suma, as mudanças teórico-metodológicas entre as regionalizações reverberaram também outros recortes regionais que, por sua vez, refletiram as novas dinâmicas do território. A divisão regional de 1990 ainda preservou as antigas identidades regionais como um de seus pressupostos, além de levantar dados sobre a estrutura produtiva e os fluxos agrícolas e agropecuários enquanto a nova divisão de 2017 tomou como base a rede urbana e os fluxos, principalmente, dos bens e serviços. Tais mudanças se dão em função de alterações multiescalares, visto que a reestruturação econômica do último quartel do século XX condicionou, no caso brasileiro, dentre outras coisas, a expansão da rede terciária (DINIZ; GARCIA; MATOS, 2011).

Apesar das mudanças, observa-se a similitude das duas regionalizações zelarem pelos limites político-administrativos por se tratarem de divisões regionais oficiais e, portanto, serem operacionalizadas para divulgação de dados estatísticos. Além disso, as duas divisões regionais também se propuseram analisar, em maior ou menor medida, a articulação entre as cidades, partindo de um contexto de divisão social e territorial do trabalho.

Para constatar tais continuidades e descontinuidades no plano empírico resgatou-se a região geográfica intermediária de Juiz de Fora, maior região intermediária do Brasil e que substituiu, em dados oficiais, a mesorregião geográfica da Zona da Mata mineira.

Caminhos de Geografia

p. 15-33

Página 24 


\section{DA ZONA DA MATA MINEIRA À REGIÃO GEOGRÁFICA INTERMEDIÁRIA DE JUIZ DE FORA: CONTINUIDADES E DESCONTINUIDADES}

O recorte empírico a ser trabalhado nesse artigo diz respeito a porção leste do estado de Minas Gerais, área a qual se insere na formação socioespacial brasileira a partir, principalmente, da economia cafeeira (BARROS, 2020) e que, em muito, foi reconhecida face aos seus traços fisiográficos típicos da Mata Atlântica - embora, atualmente, uma de suas principais características seja a ausência de matas (MERGAREJO NETTO; DINIZ, 2005). A variável da Mata, inclusive, esteve presente desde a primeira regionalização do IBGE (IBGE, 1942 apud Contel, 2014) como fator preponderante para recorte e designação da área, sendo já qualificada como região da Mata.

As matas foram sendo substituídas, em um primeiro momento, pelas pastagens e, posteriormente e mais efetivamente, pelas lavoras de café, uma vez que a cafeicultura foi responsável até meados do século XX pela sustentação econômica e política de toda a região (MERGAREJO NETTO; DINIZ, 2005, p. 9342). Ainda no ciclo do ouro, durante o século XVIII, com a abertura do Caminho Novo, a Mata mineira se transformou em região acessória às áreas de mineração, sendo uma rota de escoamento até o porto do Rio de Janeiro. No entanto, com o declínio aurífero, toda Minas Gerais entrou em recessão, voltando ao apogeu apenas com a inserção da atividade cafeeira, sendo a área da Mata uma das mais preponderantes do estado (BARROS, 2020).

No início do século XIX a economia cafeeira foi introduzida em Minas Gerais e, em um primeiro momento, se localizou nos solos virgens da região da Mata, nos vales do Rio Pomba, do Rio Paraibuna e do Rio Paraíba, sendo a rápida difusão da cafeicultura responsável pelo rápido povoamento e desenvolvimento de infraestruturas na região (MERGAREJO NETTO; DINIZ, 2005). A região, em muito, rompeu com os moldes rústicos que predominavam no estado em função da economia do ouro e assumiu caráter mais moderno nos sistemas produtivos, refletindo o novo paradigma econômico relacionado ao café (PEDROSA, 1962). Todavia, ainda assim, quando comparada a outras regiões produtoras de café no Brasil, como o planalto paulista, a região da Mata mineira ainda se portava mais arcaica no concernente ao sistema produtivo ao fim do século XIX (MERGAREJO NETTO; DINIZ, 2005).

No tocante aos investimentos em infraestrutura ao fim do século XIX e início do XX, a cafeicultura foi responsável por induzir a modernização do sistema de transportes e financeiros e a ampliação das atividades mercantis na região. Neste momento, a abertura de rodovias e ampliação de ferrovias permitiu o escoamento da produção de cidades importantes, como Juiz de Fora, além de expandir a cultura para o norte e leste da Mata mineira, consolidando cidades como Muriaé e Ponte Nova (PAULA, 2006).

Juiz de Fora consolidou-se como centro urbano e econômico primaz da região ainda neste período, face ao seu cargo de principal entreposto comercial e, em função dos investimentos que a cidade recebia no que tange as infraestruturas de escoamento de produção, assumindo o papel de capital regional. A ampliação de sua importância regional, em muito, tem a ver com a expansão do sistema ferroviário, como colocam Giovanini e Matos (2004, p. 13):

(...) a chegada da ferrovia em Juiz de Fora incrementou seu papel regional, como já vinha acontecendo desde 1891 com a rodovia União e Indústria. Apesar de municípios importantes receberem os trilhos, como Ponte Nova em 1879, tratava-se apenas da expansão da influência viário-radial de Juiz de Fora. Tudo isso viria promover vínculos de dependência em relação ao polo regional.

Na segunda metade do século XIX, o crescimento de Juiz de Fora já estava visível, considerando que a cidade além de ser uma das maiores produtoras de café de Minas Gerais, era também "núcleo de referência no provimento de bens e serviços para toda a região" (BARROS, 2020, p. 64). Em muito, a primazia juiz-forana é atrelada a posição geográfica favorável e estratégica dessa cidade que está "no centro de gravidade do triângulo Belo Horizonte, Rio de Janeiro e São Paulo" (BARROS, 2020, p. 64) (Figura 6). 
Figura 6 - Juiz de Fora (MG): posição geográfica, 2020.
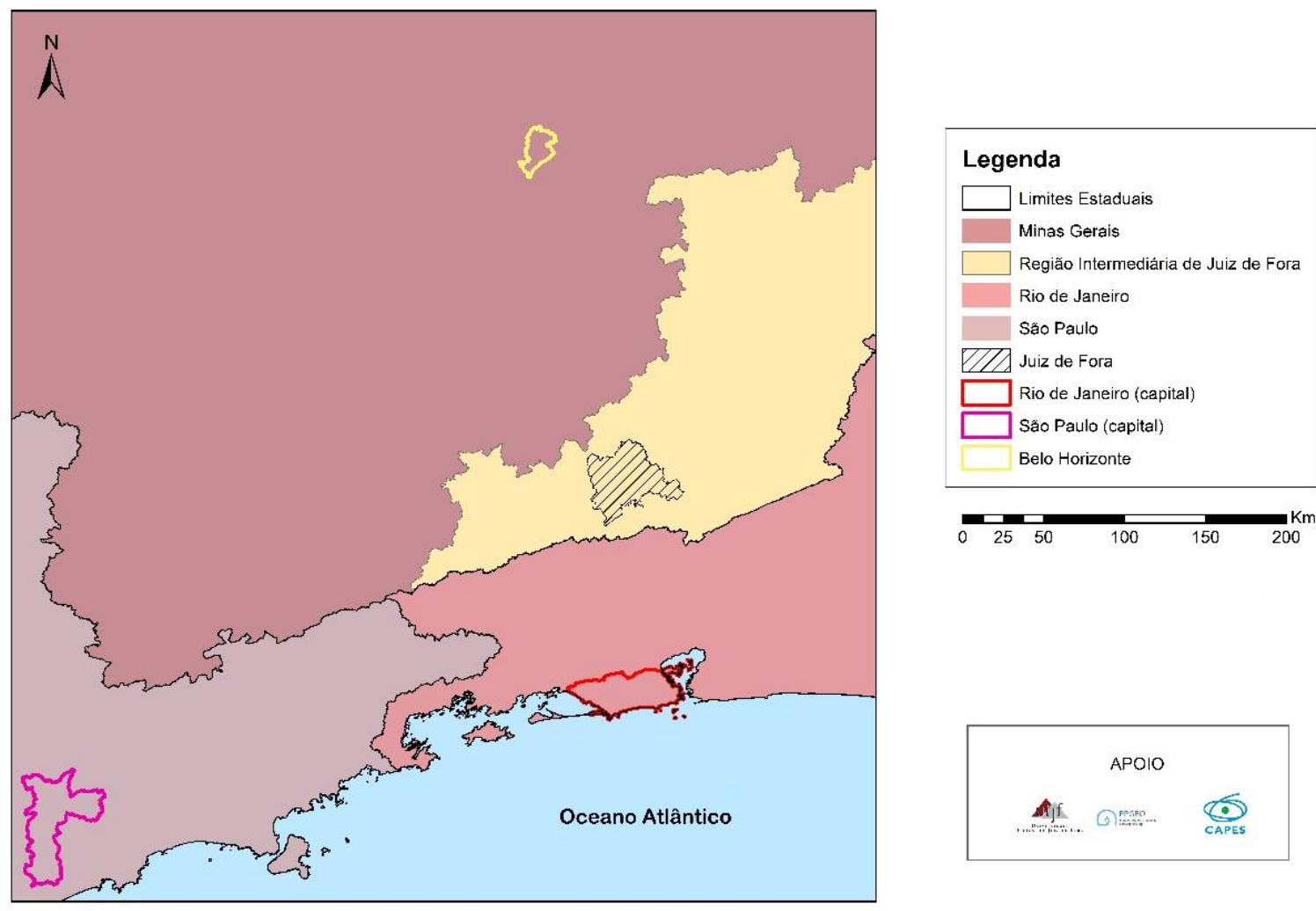

Fonte - BARROS, 2020.

A cafeicultura, ainda, foi uma das responsáveis por induzir a industrialização em Juiz de Fora, sendo este o plano de fundo necessário para a expansão e consolidação da economia capitalista na cidade ao fim do século XIX a partir, principalmente, da abolição do regime escravocrata (BARROS, 2020). Os investimentos nos setores secundários e terciários, além da infraestrutura das décadas precedentes, e a nova massa de trabalhadores assalariados coadunaram forças para a formação de um mercado local e regional.

Neste momento, face as relações sociais oriundas da amplitude regional de Juiz de Fora já era possível traçar interconexões entre os diferentes centros urbanos da Mata mineira, sendo organizada, nessa direção, uma rede de cidades organizada pelo polo juiz-forano, sendo essa rede "não só interligada, mas hierarquizada (...) de municípios e mercados de consumo (...)" (PIRES, 2004, p. 75).

A interconexão entre as cidades e a consolidação de um mercado regional foi importante não apenas para a consolidação de Juiz de Fora enquanto um polo urbano-industrial, mas também propiciou o crescimento de outras cidades que, anteriormente, estavam isoladas e apresentavam mercados locais pouco dinâmicos (PIRES, 2004; BARROS, 2020). Pires (2004) coloca que o espaço regional de Juiz de Fora, no início do século XX, beirava um milhão de habitantes e as principais cidades da área eram articuladas, de maneira mais próxima ou distante, à Juiz de Fora. É importante colocar que as cidades reconhecidas por Pires (2004), com base no recenseamento de 1920, sempre despontaram como polos microrregionais nas propostas de regionalização do IBGE, sobremaneira, nas duas últimas (IBGE, 1990; 2017) as quais a coesão socioeconômica e a articulação entre as cidades apresentaram-se como variáveis importantes.

No quadro 1 é possível identificar as cidades reconhecidas em Pires (2004) com as maiores populações urbanas na Mata mineira, ainda em 1920, e como a centralidade delas permaneceu para as regionalizações do fim do século XX e início do século XXI. 
Da Zona da Mata/MG à Região Geográfica Intermediária

de Juiz de Fora/MG: continuidades e descontinuidades

nas propostas de regionalização do IBGE

Samarane Fonseca de Souza Barros

Quadro 1 - Cidades principais em 1920 e suas posições centrais nas regionalizações de 1990 e 2017.

\begin{tabular}{|c|c|c|}
\hline CIDADE & POSIÇÕES NA REGIONALIZAÇÃO DE 1990 & POSIÇÕES NA REGIONALIZAÇÃO DE 2017 \\
\hline Juiz de Fora & $\begin{array}{l}\text { a) Mesorregião da Zona da Mata } \\
\text { b) Microrregião de Juiz de Fora }\end{array}$ & $\begin{array}{l}\text { a) Região Geográfica Intermediária de Juiz de } \\
\text { Fora } \\
\text { b) Região Geográfica Imediata de Juiz de Fora }\end{array}$ \\
\hline Carangola & $\begin{array}{l}\text { a) Mesorregião da Zona da Mata } \\
\text { b) Microrregião de Muriaé }\end{array}$ & $\begin{array}{l}\text { a) Região Geográfica Intermediária } \\
\text { de Juiz de Fora } \\
\text { b) Região Geográfica Intermediária de } \\
\text { Carangola }\end{array}$ \\
\hline Manhuaçu & $\begin{array}{l}\text { a) Mesorregião da Zona da Mata } \\
\text { b) Microrregião de Manhuaçu }\end{array}$ & $\begin{array}{l}\text { a) Região Geográfica Intermediária de } \\
\text { Juiz de Fora } \\
\text { b) Região Geográfica Imediata de } \\
\text { Manhuaçu }\end{array}$ \\
\hline Muriaé & $\begin{array}{l}\text { a) Mesorregião da Zona da Mata } \\
\text { b) Microrregião de Muriaé }\end{array}$ & $\begin{array}{l}\text { a) Região Geográfica Intermediária de Juiz de } \\
\text { Fora } \\
\text { b) Região Geográfica Imediata de Muriaé }\end{array}$ \\
\hline Ubá & $\begin{array}{l}\text { a) Mesorregião da Zona da Mata } \\
\text { b) Microrregião de Ubá }\end{array}$ & $\begin{array}{l}\text { a) Região Geográfica Intermediária de Juiz de } \\
\text { Fora } \\
\text { b) Região Geográfica Imediata de Ubá }\end{array}$ \\
\hline Cataguases & $\begin{array}{l}\text { a) Mesorregião da Zona da Mata } \\
\text { b) Microrregião de Cataguases }\end{array}$ & $\begin{array}{l}\text { a) Região Geográfica Intermediária de Juiz de } \\
\text { Fora } \\
\text { b) Região Geográfica Imediata de Cataguases }\end{array}$ \\
\hline Leopoldina & $\begin{array}{l}\text { a) Mesorregião da Zona da Mata } \\
\text { b) Microrregião de Cataguases }\end{array}$ & $\begin{array}{l}\text { a) Região Geográfica Intermediária de Juiz de } \\
\text { Fora } \\
\text { b) Região Geográfica Imediata de Cataguases }\end{array}$ \\
\hline Rio Pomba & $\begin{array}{l}\text { a) Mesorregião da Zona da Mata } \\
\text { b) Microrregião de Ubá }\end{array}$ & $\begin{array}{l}\text { a) Região Geográfica Intermediária de Juiz de } \\
\text { Fora } \\
\text { b) Região Geográfica Imediata de Ubá }\end{array}$ \\
\hline Mar de Espanha & $\begin{array}{l}\text { a) Mesorregião da Zona da Mata } \\
\text { b) Microrregião de Juiz de Fora }\end{array}$ & $\begin{array}{l}\text { a) Região Geográfica Intermediária de Juiz de } \\
\text { Fora } \\
\text { b) Região Geográfica Imediata de Juiz de Fora }\end{array}$ \\
\hline Além Paraíba & $\begin{array}{l}\text { a) Mesorregião da Zona da Mata } \\
\text { b) Microrregião de Cataguases }\end{array}$ & $\begin{array}{l}\text { a) Região Geográfica Intermediária de Juiz de } \\
\text { Fora } \\
\text { b) Região Geográfica Imediata de Além } \\
\text { Paraíba }\end{array}$ \\
\hline
\end{tabular}

Fonte - Pires, 2004; IBGE, 1990; 2017. Organização Própria.

A partir do quadro 1 é possível observar que as principais centralidades da Mata mineira foram sendo construídas ao longo do tempo, principalmente, a partir da economia cafeeira e posterior industrialização, sendo organizadas - ainda hoje - a partir do centro mais pujante representado por 
Juiz de Fora. As cidades que não eram polos de Microrregiões em 1990 ou, atualmente, não são polos de Regiões Geográficas Imediatas, estão próximas, significativamente, de centros de igual ou maior dinamismo, como no caso de Leopoldina que dista cerca de $24 \mathrm{~km}$ de Cataguases, Rio Pomba que está aproximadamente a $39 \mathrm{~km}$ de Ubá e Mar de Espanha cerca de $60 \mathrm{~km}$ de Juiz de Fora.

A partir de 1930 o que se observou foi um grande declínio da economia cafeeira na região, sendo que a agricultura secundária e familiar e o setor terciário despontaram como principais fontes de renda dos habitantes da região e, assim permanece até os dias atuais (BARROS, 2020). No entanto, a primazia dos municípios anteriormente vinculados ao apogeu cafeeiro se manteve e estes continuaram aparecendo como articuladores da vida local e regional atrelados ao comando superior de Juiz de Fora. Esta constatação pode ser observada a partir das regionalizações propostas pelo IBGE, sendo que as duas últimas foram aqui resgatadas por apresentarem, em suas metodologias, as variáveis de consistência interna e articulação entre as cidades.

Como já visto, as mesorregiões geográficas eram, em muito, delimitadas pelo processo social, quadro natural e identidade regional, logo a mesorregião da Zona da Mata foi definida, para além da característica da paisagem natural relacionada a presença de Mata Atlântica, pelos condicionantes da economia cafeeira que garantiram sua hegemonia política e cultural interna. A mesorregião era composta por sete microrregiões que totalizavam 142 cidades. As microrregiões recebiam os nomes das cidades mais importantes econômica e politicamente responsáveis pela articulação da hinterlândia imediata, sendo elas: Ubá, Ponte Nova, Viçosa, Juiz de Fora, Muriaé, Cataguases e Manhuaçu. Vale colocar que a despeito de apresentarem características semelhantes por estarem na Mata mineira, cada uma das microrregiões apresentava particularidades no que tange suas estruturas produtivas e sociais internas.

As estruturas e variáveis utilizadas pela regionalização de 1990, ainda, eram muito vinculadas ao ambiente agrícola, considerando os dados do censo agropecuário e, ainda, à estrutura produtiva, levando em consideração a interiorização da industrialização brasileira e suas conseguintes mudanças no território. No entanto, a regionalização de 1990 já dava indícios da importância da articulação entre as cidades em uma perspectiva da divisão do trabalho e do desenvolvimento capitalista, uma vez que a organização do espaço sob este âmbito traz consigo uma "inevitável desigualdade da organização espacial que comporta diferentes formas de subordinação do trabalho ao capital (...)" (IBGE, 1990, p. 7).

Contel (2014) coloca que, paradoxalmente, apenas a partir de um momento político neoliberal no Brasil que o IBGE passa a se portar de maneira mais crítica, considerando, para além da ideia de desenvolvimento desigual, conceitos do materialismo histórico em suas propostas de regionalização.

A despeito da regionalização de 1990 já dar peso aos vínculos e comunicações entre as cidades, principalmente, na escala microrregional, foi a partir da regionalização de 2017 que o IBGE se preocupou mais diretamente com os fluxos de pessoas e capitais, agora, zelando, mormente, pelo setor de bens e serviços. A regionalização foi proposta a partir de centros notáveis na hierarquia urbana para organização das regiões geográficas intermediárias e imediatas que materializavam, por sua vez, a posição dos centros urbanos dentro da divisão social e territorial do trabalho. Em 2017, então, a rede urbana foi o elemento central que conduziu a análise regional (IBGE, 2017).

Se Juiz de Fora já era considerada a capital regional para a área ainda no século XIX, no século XXI a cidade assim se manteve. A Zona da Mata foi substituída por Região Geográfica Intermediária de Juiz de Fora por essa cidade ser responsável por manter fluxos horizontais e transversais com espaços mais próximos ou mais distantes. A variável da contiguidade espacial alterada para uma ordem mais reticular, fez com que outras cidades fossem adicionadas à região de Juiz de Fora e ela totalizasse 146 cidades divididas em 10 regiões imediatas.

Dentre as cidades que se destacavam na regionalização de 1990 em uma escala microrregional, as mesmas se mantiveram como polos de regiões imediatas, sendo que além das sete outras três regiões imediatas foram criadas sob a polarização de, a saber: São João Nepomuceno-Bicas, Além Paraíba e Carangola. 
O quadro comparativo entre as duas regionalizações demonstra pouca oscilação para a área, reiterando a supremacia juiz-forana frente às outras cidades, considerando que este contexto urbano é marcado por um pouco mais de $70 \%$ de cidades de menos de 10.000 habitantes e pouco pujantes economicamente (BARROS, 2020). As mudanças mais significativas foram dos municípios que desintegraram a Zona da Mata mineira e passaram a compor a Região Geográfica Intermediária de Barbacena, região esta vizinha a Juiz de Fora. Por outro lado, alguns municípios que antes eram pertencentes das mesorregiões Sul/Sudoeste de Minas e do Vale do Rio Doce passaram a compor a Região Geográfica Intermediária de Juiz de Fora. Estas mudanças foram em função de maior ou menor articulação com a cidade de Juiz de Fora.

Uma síntese das mudanças ocorridas entre a Zona da Mata e a Região Geográfica Intermediária de Juiz de Fora pode ser apreendida a partir do quadro 2 e da figura 7.

Quadro 2 - Síntese das mudanças entre as regionalizações.

\begin{tabular}{|c|c|}
\hline $\begin{array}{c}\text { Municípios que deixaram de pertencer a Zona } \\
\text { da Mata mineira }\end{array}$ & $\begin{array}{l}\text { Municípios que passaram a integrar a Região } \\
\text { Geográfica Intermediária de Juiz de Fora }\end{array}$ \\
\hline $\begin{array}{l}\text { Alto Rio Doce (atualmente faz parte da Região } \\
\text { Intermediária de Barbacena) }\end{array}$ & $\begin{array}{l}\text { Alvinópolis (pertencia a mesorregião } \\
\text { metropolitana de } \mathrm{BH} \text { ) }\end{array}$ \\
\hline $\begin{array}{l}\text { Cipotânea (atualmente faz parte da Região } \\
\text { Intermediária de Barbacena) }\end{array}$ & $\begin{array}{l}\text { Andrelândia (pertencia a mesorregião } \\
\text { sul/sudoeste de Minas) }\end{array}$ \\
\hline $\begin{array}{l}\text { Lamim (atualmente faz parte da Região } \\
\text { Intermediária de Barbacena) }\end{array}$ & $\begin{array}{c}\text { Arantina (pertencia a mesorregião sul/sudoeste de } \\
\text { Minas) }\end{array}$ \\
\hline $\begin{array}{l}\text { Piranga (atualmente faz parte da Região } \\
\text { Intermediária de Barbacena) }\end{array}$ & $\begin{array}{l}\text { Bocaina de Minas (pertencia a mesorregião } \\
\text { sul/sudoeste de Minas) }\end{array}$ \\
\hline $\begin{array}{l}\text { Raul Soares (atualmente faz parte da Região } \\
\text { Intermediária de Ipatinga) }\end{array}$ & $\begin{array}{l}\text { Bom Jardim de Minas (pertencia a mesorregião } \\
\text { sul/sudoeste de Minas) }\end{array}$ \\
\hline $\begin{array}{l}\text { Rio Espera (atualmente faz parte da Região } \\
\text { Intermediária de Barbacena) }\end{array}$ & $\begin{array}{c}\text { Conceição de Ipanema (pertencia a mesorregião } \\
\text { do Vale do Rio Doce) }\end{array}$ \\
\hline $\begin{array}{c}\text { Santa Rita do Ibitipoca (atualmente faz parte da } \\
\text { Região Intermediária de Barbacena) }\end{array}$ & $\begin{array}{c}\text { Diogo de Vasconcelos (pertencia a mesorregião } \\
\text { metropolitana de } \mathrm{BH} \text { ) }\end{array}$ \\
\hline $\begin{array}{l}\text { Senhora de Oliveira (atualmente faz parte da } \\
\text { Região Intermediária de Barbacena) }\end{array}$ & $\begin{array}{c}\text { Ipanema (pertencia a mesorregião do Vale do Rio } \\
\text { Doce) }\end{array}$ \\
\hline \multirow[t]{5}{*}{$\begin{array}{l}\text { Vermelho Novo (atualmente faz parte da Região } \\
\text { Intermediária de Ipatinga) }\end{array}$} & $\begin{array}{l}\text { Liberdade (pertencia a mesorregião sul/sudoeste } \\
\text { de Minas) }\end{array}$ \\
\hline & $\begin{array}{c}\text { Mutum (pertencia a mesorregião do Vale do Rio } \\
\text { Doce) }\end{array}$ \\
\hline & $\begin{array}{l}\text { Passa-Vinte (pertencia a mesorregião } \\
\text { sul/sudoeste de Minas) }\end{array}$ \\
\hline & $\begin{array}{c}\text { Pocrane (pertencia a mesorregião do Vale do Rio } \\
\text { Doce) }\end{array}$ \\
\hline & $\begin{array}{c}\text { Taparuba (pertencia a mesorregião do Vale do } \\
\text { Rio Doce) }\end{array}$ \\
\hline
\end{tabular}

Fonte - BARROS, 2020, p.79. 
Figura 7 - Regionalizações: comparações entre 1990 e 2017.
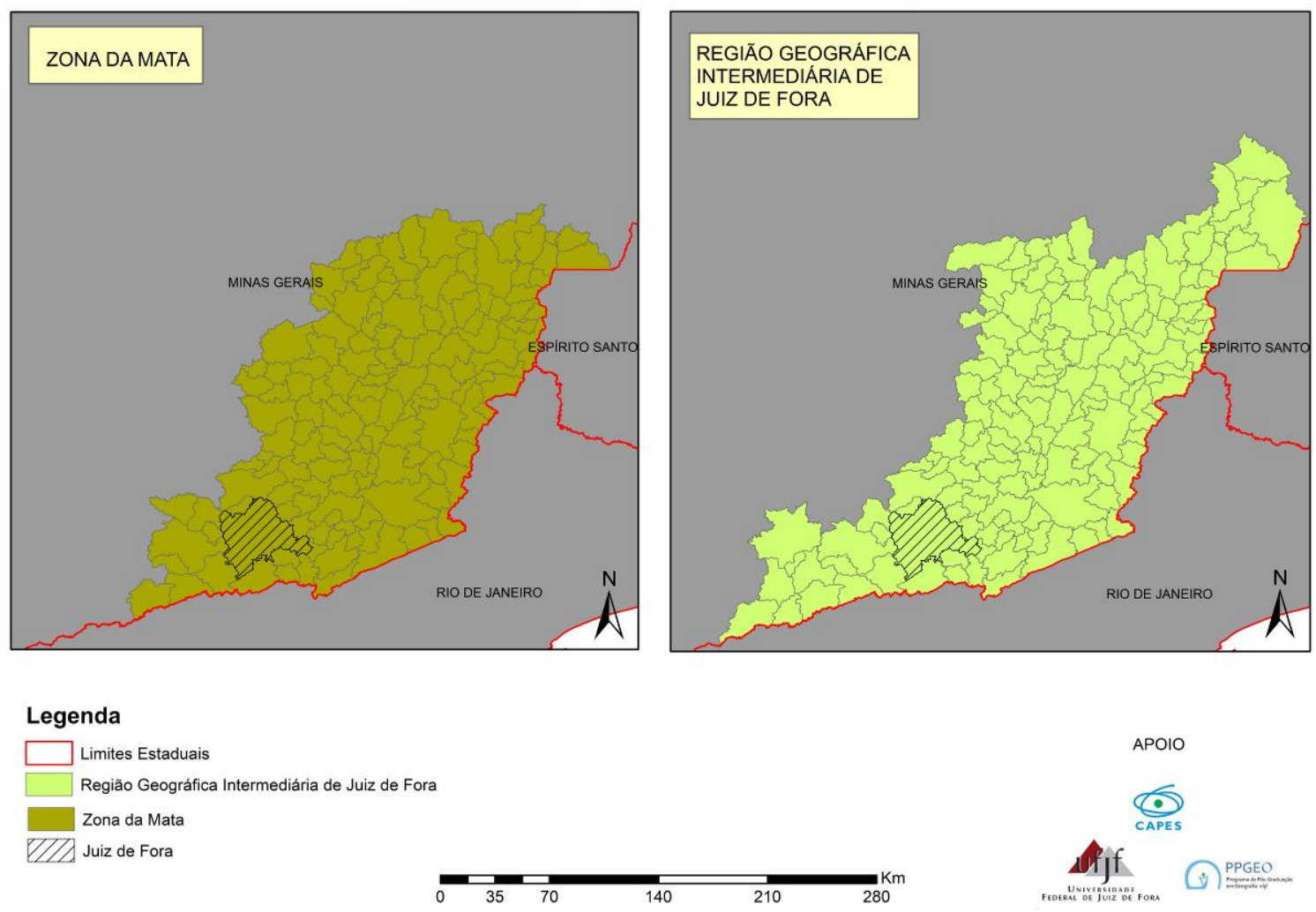

Fonte - BARROS, 2020, p. 77.

A partir da comparação entre os quadros de regionalização, nota-se que pouca coisa mudou, sendo o papel de Juiz de Fora mais uma vez ratificado enquanto principal centro da região. Desde os estudos sobre regiões urbanas em 1972 a cidade já vinha sendo apontada como "a única cidade que na metade sul de Minas Gerais, realmente, desenvolveu uma grande projeção regional" (IBGE, 1972, p. 21). Como visto, a estruturação da cidade, em muito, atrelou-se ao capital cafeeiro que foi um dos subsídios para sua industrialização e ascensão dentro da rede urbana (BARROS, 2020).

Como a rede urbana foi uma das principais proxies para a regionalização de 2017 , observou-se que tanto a região intermediária de Juiz de Fora quanto as regiões imediatas vinculadas a ela tem muitas interfaces com as propostas de áreas de influência da REGIC (IBGE, 2008), no entanto, a diferença é que as regiões intermediárias e imediatas respeitam os limites político-administrativos por se tratar de uma divisão regional oficial e para fins estatísticos. Ainda, constatou-se que o fato de as cidades deixarem a região intermediária de Juiz de Fora e irem para a região de Barbacena atrela-se mais ao crescimento da segunda cidade do que a perda de influência da primeira, analisando comparativamente os três estudos de REGIC (IBGE, 1987; 2000; 2008) que apontam o crescimento da região de influência de Barbacena ao longo dos anos e das publicações.

Em síntese, observou-se que as continuidades foram maiores que as descontinuidades entre as regionalizações propostas em 1990 e 2017 em que a estrutura econômica e urbana é reverberada e as cidades importantes assim se mantém, anteriormente como polos de microrregiões geográficas e atualmente como polos de regiões geográficas imediatas. As regionalizações revelaram, portanto, aspectos históricos e funcionais do território, sendo que a última regionalização salientou, ainda mais, a articulação entre as cidades. 


\section{CONSIDERAÇÕES FINAIS}

As propostas de regionalização do IBGE correspondem, cada uma delas, a um contexto espaçotemporal específico, bem como se associam aos momentos históricos e políticos de quando são elaboradas. Nesta direção, não é possível afirmar que há uma regionalização melhor que a outra: cada regionalização cumpre um objetivo específico e responde pelas demandas de seu determinado contexto.

Desde a sua fundação no início do século XX, o IBGE apresentou quatro propostas de divisão regional para o Brasil, sendo a primeira pautada em zonas fisiográficas, a segunda em microrregiões homogêneas, a terceira em mesorregiões e microrregiões geográficas e, a última em regiões geográficas intermediárias e imediatas. Cada uma dessas regionalizações, em seus pressupostos metodológicos e conceituais, trouxe à baila atualizações objetivas do território nacional e novas delimitações teóricas sobre a própria noção de região desenvolvida pelo instituto. Uma nova regionalização, então, não anula a precedente em termos gerais, ela atualiza conforme as novas demandas o quadro anterior.

A mudança no perfil do Brasil a partir da introdução e aceleração da industrialização e a maior difusão do meio técnico-científico pelo território nacional, fez com que a partir da regionalização de 1969 as regiões naturais e as perspectivas fisiográficas tivessem as suas importâncias minimizadas em função do crescimento das áreas urbanas e maior complexidade das cidades ao interior do país. Tal feito se concretizou, ainda mais, nas regionalizações de 1990 e 2017 em que a rede urbana brasileira foi um importante plano de fundo para as operacionalizações de tais estudos.

No que diz respeito à área analisada, ela foi escolhida, em muito, por ser a maior região geográfica intermediária do país. Para a região geográfica intermediária de Juiz de Fora (IBGE, 2017), então, observou-se que as permanências foram maiores que as rupturas quando retomada a mesorregião da zona da mata mineira (IBGE, 1990). A mudança mais significativa foi que aumentou o número de municípios da região, demonstrando que Juiz de Fora desempenha uma importante centralidade para o estado de Minas Gerais, uma vez que os polos das regiões intermediárias são definidos pelos papéis de hierarquia que exercem na rede urbana. Ademais, entre os números de microrregiões para o número de regiões imediatas também observou um aumento: se antes eram sete as microrregiões, atualmente são dez as regiões imediatas, demonstrando que algumas cidades ou arranjos de cidades ampliaram a importância para suas respectivas hinterlândias imediatas, como Além Paraíba, São João Nepomuceno-Bicas e Carangola. Por outro lado, as cidades que deixaram a região intermediária de Juiz de Fora passaram a integrar a região intermediária de Barbacena, vizinha a de Juiz de Fora.

A regionalização de 2017, portanto, veio ratificar a importância de Juiz de Fora para a área onde está localizada, visto que a cidade desde a economia cafeeira despontou no estado como uma das principais cidades e na região como a principal centralidade ou capital regional. A rede urbana regional é organizada a partir de Juiz de Fora e em função da articulação entre as cidades que a regionalização de 2017 lançou luz é possível falar que os nós de articulação dessa rede são os polos das regiões imediatas - que desde tempos remotos também se comportam como cidades importantes para a área.

Dentre algumas constatações, é possível notar que as regiões delimitadas são coincidentes, em muito, as áreas de influência das cidades identificada pelo IBGE em 2008 (IBGE, 2008). Não à toa, este foi um dos documentos utilizados nos procedimentos metodológicos da regionalização de 2017 que tinha, entre outros objetivos, ressaltar a articulação entre as cidades em uma ordem tanto horizontal como reticular.

Observou-se, então, que as continuidades entre as regionalizações de 1990 e 2017 vão em direção de ressaltar a ordem urbana, cultural e política que está vigente desde a estruturação da área de estudo.

No caso das divisões regionais do IBGE, em muito, elas seguem a direção de compartimentar o território nacional conforme as dinâmicas das épocas em que são propostas, sendo importantes datações espaço-temporais. Portanto, cada regionalização apresenta subsídios teórico-metodológicos distintos e objetivos diversos, apesar de no final todas somarem para o quadro de divulgação dos dados estatísticos da instituição. Mais uma vez, não há uma regionalização mais importante que outra, o que há são inúmeras possibilidades de recortes regionais considerando as dinâmicas e possibilidades de rupturas - e permanências - no território nacional. 


\section{REFERÊNCIAS}

ALMEIDA, R. S. A Geografia do IBGE: um esboço histórico. Revista do Instituto Histórico e Geográfico Brasileiro. V. 164, N. 418, 2003, pp. 79-99.

AMORIM FILHO, O. B; SERRA, R.V. Evolução e perspectivas do papel das cidades médias no planejamento Urbano e Regional. In: ANDRADE, T.A.; SERRA, R.V. (Org.). Cidades médias brasileiras. Rio de Janeiro: IPEA, 2001. pp. 1-34.

BARROS, S. F. S. Análise comparativa de três cidades médias mineiras: Ponte Nova, Viçosa e Ubá no contexto da rede urbana da região Geográfica Intermediária de Juiz de Fora/MG. Dissertação (Mestrado em Geografia). Universidade Federal de Juiz de Fora, Juiz de Fora, 2020. 194p.

CONTEL, F. B. As divisões regionais do IBGE no século XX (1942, 1970 e 1990). Terra Brasilis (Nova Série). Revista da Rede Brasileira de História da Geografia e Geografia Histórica. V. 3, 2014, pp. 1-20. https://doi.org/10.4000/terrabrasilis.990

DINIZ, A. M. A.; BATELLA, W. B. O estado de Minas Gerais e suas regiões: um resgate histórico das principais propostas oficiais de regionalização. Sociedade e Natureza. Uberlândia, n. 33, 2005, pp. 59-77.

DINIZ, C. C. Desenvolvimento poligonal no Brasil: nem desconcentração nem contínua polarização. Nova Economia. 3 (1), pp. 35-64, 1993.

DINIZ, L. H. F.; GARCIA, R. A.; MATOS, R. E. S. Distribuição das atividades terciárias no Brasil. Cadernos do Leste. Vol 11, N. 11, 2011, pp. 50-69.

GALVÃO, M. V.; FAISSOL, S. A divisão regional da década de 1940: suas características e fundamentos. Revista Brasileira de Geografia. Rio de Janeiro. V. 31, N. 4, 1969, pp. 181-218.

GIOVANINI, R. R.; MATOS, R. E. S. Geohistória econômica da Zona da Mata Mineira. In: SEMINÁRIO SOBRE A ECONOMIA MINEIRA , 11, 2004, Belo Horizonte..Anais [...] Diamantina. Belo Horizonte: CEDEPLAR, 2004.

HAESBAERT, R. Regiões transfroteiriças e redes brasileiras no Mercosul. In: ENCONTRO DE GEÓGRAFOS DA AMÉRICA LATINA, 8, 2001.Santiago/Chile. Anais [...] Santiago/Chile: EGAL, 2001.

O mito da desterritorialização: do fim dos territórios à multiterritorialidade. Rio de Janeiro: Bertrand Brasil, 2004, 395p.

IBGE. Instituto Brasileiro de Geografia e Estatística. Divisão do Brasil em Microrregiões Homogêneas 1968. Rio de Janeiro: Ministério do Planejamento e Coord. Geral /Fundação IBGE. 1970. 564p.

Divisão do Brasil em Regiões Funcionais Urbanas. Rio de Janeiro: Instituto Brasileiro de Geografia/Departamento de Geografia. 1972. 112 p.

Região de influência das cidades 1978. Rio de Janeiro: IBGE, 1987.

Divisão do Brasil em Mesorregiões e Microrregiões Geográficas. Vol I. Rio de Janeiro:

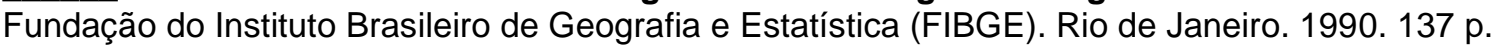

Região de influência das cidades 1993. Rio de Janeiro: IBGE, 2000.

Regiões de influência das cidades 2007. Rio de Janeiro: IBGE, 2008, 201p.

Divisão Regional do Brasil em Regiões Geográficas Imediatas e Regiões Geográficas Intermediárias 2017. Rio de Janeiro: IBGE, 2017, 83p.

LACOSTE, Y. A Geografia - Isso serve em primeiro lugar, para fazer a guerra. Campinas: Papirus, 1988 [1976].

MERGAREJO NETTO, M.; DINIZ, A. M. A. A estagnação sócio-econômica da Zona da Mata de Minas Gerais: uma abordagem geohistórica. In: ENCONTRO DE GEÓGRAFOS DA AMÉRICA LATINA, 2005, 10, São Paulo. Anais [...] São Paulo: Universidade de São Paulo, 2005.

PAULA, R. Z. A. Região e regionalização: um estudo da formação regional da Zona da Mata de Minas Gerais. Revista de História Econômica \& Economia Regional Aplicada. Vol 1, N. 1, Jul/Dez, 2006, pp. 66-80. 
PEDROSA, M.X. Zona silenciosa da historiografia mineira - A Zona da Mata. Revista do Instituto Histórico e Geográfico de Minas Gerais. Belo Horizonte, N.9, pp. 189-230, 1962.

PIRES, A. Café, finanças e banco: uma análise do sistema financeiro da Zona da Mata de Minas Gerais (1889/1930). Tese (Doutorado em História Econômica). Programa de Pós-Graduação em História Econômica, Universidade de São Paulo, São Paulo, 425p, 2004.

RUA, J.; WASZKIAVICUS, F. A; TANNURI, M. R. P.; PÓVOA NETO, H. Para ensinar Geografia. Rio de Janeiro: Access Editora, 1993, 311p.

SANTOS, M.; SILVEIRA, M.L. O Brasil: território e sociedade no início do século XXI. Rio de Janeiro: Record, 2008.

SOUZA, M. L. Os conceitos fundamentais da pesquisa sócio-espacial. $1^{\underline{a}}$ ed. Rio de Janeiro: Bertrand Brasil, 2013.

Recebido em: 02/05/2020

Aceito para publicação em: 13/08/2020 